\title{
EKSISTENSI BADAN USAHA MILIK DESA (BUMDES) DALAM PEMBANGUNAN EKONOMI DI DESA
}

\author{
I Wayan Sutrisna \\ Fakultas Ilmu Sosial dan Ilmu Politik Univ. Mahendradatta \\ e-mail : sutrisna76@yahoo.co.id
}

\begin{abstract}
Abstrak - Pembangunan yang dilakukan di desa saat ini mengalami perubahan yang semakin cepat, sehingga dibutuhkan para aparatur pemerintah desa yang benar-benar dapat menyesuaikan dengan keadaan yang terus berubah. Pemerintah desa juga harus mampu menggali potensi desa yang dapat digunakan untuk meningkatkan Pendapatan Asli Desa (PAD), yang bermuara pada peningkatan kesejahteraan seluruh masyarakat desa. Pemberdayaan masyarakat mutlak diperlukan sehingga masyarakat menjadi kuat khususnya dalam bidang ekonomi. Badan Usaha Milik Desa (BUMDes) merupakan lembaga pemberdayaan ekonomi masyarakat desa, lembaga ini adalah wadah bagi masyarakat desa dalam memperkuat perekonomian menuju kearah kesejahteraan. Pemerintah diharapkan terus berupaya memberikan pemahaman kepada pemerintah desa akan pentingnya keberadaan lembaga ekonomi ini dalam pemberdayaan masyarakat desa. Penguatan kelembagaan BUMDes harus dijadikan prioritas oleh pemerintah desa yang didukung oleh seluruh lapisan masyarakat. Lembaga usaha desa yang dikelola secara baik akan memberikan manfaat yang sangat besar bagi kehidupan masyarakat desa. Masyarakat akan menerima manfaat secara individu utamanya yang terlibat secara langsung dalam usaha desa ini. Selain itu BUMDes yang dikelola dengan baik akan mampu menambah keuangan pemerintah desa yang digunakan dalam pembangunan desa guna menekan angka kemiskinan dan sekaligus meningkatkan kesejahteraan masyarakat. Tulisan ini menggunakan kajian dengan pendekatan studi literatur yang bertujuan untuk mengetahui tentang eksistensi Badan Usaha Milik Desa (BUMDes) dalam Pembangunan Ekonomi di Desa.
\end{abstract}

Kata kunci : pembangunan, perekonomian, partisipatif dan masyarakat desa.

Abstract - The development carried out in the village is currently undergoing increasingly rapid changes, so that village government officials are needed who can really adapt to changing conditions. The village government must also be able to explore the potential of the village which can be used to increase Village Original Income (PAD), which leads to improving the welfare of all village communities. Community empowerment is absolutely necessary so that society becomes strong, especially in the economic field. Community empowerment is absolutely necessary so that society becomes strong, especially in the economic field. Village Owned Enterprises (BUMDes) is an economic empowerment institution for rural communities, this institution is a forum for village communities to strengthen the economy towards prosperity. It is hoped that the government will continue to strive to provide understanding to the village government of the importance of the existence of this economic institution in empowering village communities. Strengthening BUMDes institutions must be a priority by the village government, supported by all levels of society. Well-managed village business institutions will provide enormous benefits to the life of village communities. The community will receive benefits individually, especially those who are directly involved in this village business. In addition, BUMDes that are well managed will be able to increase village government finances used in village development to reduce poverty and at the same time improve community welfare. This paper uses a study with a literature study approach which aims to find out about the existence of BUMDes in Economic Development in Villages.

Key words: development, economy, participatory and rural communities. 


\section{PENDAHULUAN}

Pembangunan nasional yang dilaksanakan oleh bangsa Indonesia memilki tujuan yakni mewujudkan masyarakat sejahtera, adil dan makmur. Untuk mewujudkan tujuan dari pembangunan nasional ini pemerintah saat ini terus menggejot pembangunan infrastruktur di seluruh wilayah Indonesia. Kesejahteraan masyarakat yang menjadi tujuan pembangunan ini adalah kesejahteraan di seluruh wilayah negeri. Adanya ketimpangan kesejahteraan antara daerah perkotaan dan daerah pedesaan membuat pemerintah saat ini memberikan prioritas anggaran langsung ke desa. Salah satu program yang dicanangkan pemerintah yang tertuang dalam Nawa Cita adalah Membangun Indonesia dari pinggiran dengan memperkuat daerah-daerah dan desa dalam kerangka negara kesatuan. Hal ini menunjukkan bahwa untuk meningkatkan kesejahteraan masyarakat secara keseluruhan maka desa harus mendapatkan perhatian lebih dalam pelaksanaan pembangunan nasional.

Dalam Undang-Undang Nomor 6 Tahun 2014 tentang Desa, menyebutkan bahwa Desa adalah desa dan desa adat atau yang disebut dengan nama lain, selanjutnya disebut Desa, adalah kesatuan masyarakat hukum yang memiliki batas wilayah yang berwenang untuk mengatur dan mengurus urusan pemerintahan, kepentingan masyarakat setempat berdasarkan prakarsa masyarakat, hak asal usul, dan/atau hak tradisional yang diakui dan dihormati dalam sistem pemerintahan Negara Kesatuan Republik Indonesia. Aturan ini telah memberikan kewenangan kepada pemerintah desa untuk mengatur pemerintahannya dalam mewujudkan pemerintahan desa yang lebih baik menuju peningkatan kesejahteraan masyarakat. Pembangunan desa sebagai bagian dari Pembangunan Nasional dan daerah, pada dasarnya merupakan keseluruhan upaya dalam rangkaian kegiatan yang dilaksanakan secara berencana oleh
Pemerintah dan masyarakat, untuk meningkatkan kesejahteraan masyarakat dari berbagai aspek kehidupan baik ekonomi, politik, sosial dan kebudayaan.

Paradigma pembangunan desa saat ini mengalami perubahan yang semakin cepat, sehingga dibutuhkan para aparatur pemerintah desa yang benar-benar dapat menyesuaikan dengan keadaan yang terus berubah, saat ini tuntutan masyarakat mengenai pelayanan kepada masyarakat merupakan faktor yang penting dalam penyelenggaraan pemerintah khususnya di desa. Pemerintah desa juga harus mampu menggali potensi desa yang dapat digunakan untuk meningkatkan Pendapatan Asli Desa (PAD), yang bermuara pada peningkatan kesejahteraan seluruh masyarakat. Pemberdayaan masyarakat mutlak diperlukan sehingga masyarakat menjadi kuat khususnya dalam bidang ekonomi.

Perkembangan pembangunan yang semakin cepat dan sangat kompleks menuntut seluruh komponen yang terlibat dalam proses pembangunan mampu mewujudkan apa yang menjadi tujuan dari pembangunan nasional. Landasan pemikiran dalam mengatur mengenai desa adalah keanekaragaman, partisipasi, otonomi asli, demokratisasi dan pemerdayaan masyarakat. Hal ini menunjukkan bahwa desa telah diberikan hak otonomi dalam proses pembangunan. Namun otonomi desa tidak berarti kedaulatan desa, melainkan suatu kewenangan dalam kerangka otonomi daerah. Keragaman desa membawa konsekwensi yang luas diantaranya desa dapat menentukan arah masa depannya serta penggunaan istilah istilah sesuai dengan kearifan lokal masing-masing. Selain itu, desa juga dituntut untuk mampu membangkitkan partisipasi masyarakatnya dalam proses pembangunan dengan pemberdayaan masyarakat secara maksimal guna menekan jumlah masyarakat miskin yang ada di wilayahnya.

Badan Pusat Statistik (BPS) tanggal 
15 Januari 2020 merilis data yang menyebutkan bahwa Persentase penduduk miskin pada September 2019 sebesar 9,22 persen, menurun 0,19 persen poin terhadap Maret 2019 dan menurun 0,44 persen poin terhadap September 2018. Jumlah penduduk miskin pada September 2019 sebesar 24,79 juta orang, menurun 0,36 juta orang terhadap Maret 2019 dan menurun 0,88 juta orang terhadap September 2018. Persentase penduduk miskin di daerah perkotaan pada Maret 2019 sebesar 6,69 persen, turun menjadi 6,56 persen pada September 2019. Sementara persentase penduduk miskin di daerah perdesaan pada Maret 2019 sebesar 12,85 persen, turun menjadi 12,60 persen pada September 2019. Dibanding Maret 2019, jumlah penduduk miskin September 2019 di daerah perkotaan turun sebanyak 137 ribu orang (dari 9,99 juta orang pada Maret 2019 menjadi 9,86 juta orang pada September 2019). Sementara itu, daerah perdesaan turun sebanyak 221,8 ribu orang (dari 15,15 juta orang pada Maret 2019 menjadi 14,93 juta orang pada September 2019). Hal ini menunjukkan bahwa jumlah masyarakat miskin lebih banyak adadi daerah pedesaan.

Badan Usaha Milik Desa (BUMDes) merupakan lembaga ekonomi yang bertujuan mendorong upaya meningkatkan pendapatan masyarakat desa sesuai dengan kebutuhan dan potensi desa. BUMDes sebagai badan usaha yang seluruh atau sebagian besar modalnya dimilki oleh desa melalui penyertaan secara langsung yang berasal dari kekayaan desa yang dipisahkan guna mengelola aset, jasa pelayanan, dan usaha lainnya untuk sebesar-besarnya untuk kesejahteraan masyarakat desa (Fkun, 2019). Sedangkan Harmiati dan Zulhakim (2017) dalam kajiannya mengemukakan bahwa Eksistensi atau penguatan peran BUMDes dalam mengembangkan usaha dan perekonomian masyarakat desa memerlukan penanganan yang komprehensif, sehingga tumbuhnya ekonomi nasional ditopang kokoh oleh perekonomian desa yang kokoh dan terarah. Ramadana et.al (2013) juga mengkaji keberadaan BUMDes yang menyatakan bahwa Badan Usaha Milik Desa adalah unit ekonomi multi sektor yang dikelola oleh pemerintah desa dan masyarakat untuk memakmurkan sebesar besarnya kepentingan masyarakat desa. Sekaligus memberikan kontribusi positif bagi Pendapatan Asli Desa (PAD). Hasil-hasil kajian tersebut menunjukkan bahwa keberadaan BUMDes sangat penting dalam meningkatkan kesejahteraan masyarakat desa. Sebagai lembaga ekonomi di desa, keberadaan BUMDes diharapkan mampu menekan tingkat kemiskinan di wilayah masing-masing sehingga secara nasional mampu mengurangi jumlah penduduk miskin di Indonesia. Tulisan ini menggunakan kajian dengan pendekatan studi literatur yang bertujuan untuk mengetahui tentang eksistensi Badan Usaha Milik Desa dalam Pembangunan Ekonomi di Desa.

\section{PEMBAHASAN}

\section{BUMDes sebagai lembaga pember- dayaan ekonomi masyarakat desa}

Pembangunan pedesaan merupakan salah satu aspek penting dalam Pembangunan Nasional, artinya pembangunan pedesaan merupakan bagian integral dari Pembangunan Nasional yang bersifat menyeluruh yang keberhasilannya mutlak harus didukung oleh semua lapisan masyarakat. Pembangunan Desa sebagai bagian dari Pembangunan Nasional dan daerah, pada dasarnya merupakan keseluruhan upaya dalam rangkaian kegiatan yang dilaksanakan secara berencana oleh Pemerintah dan masyarakat, untuk meningkatkan kesejahteraan masyarakat dari berbagai aspek kehidupan baik ekonomi, politik, sosial dan kebudayaan.

Pembangunan wilayah pedesaan harus dilaksanakan dengan pola pem- 
bangunan partisipatif sehingga mayoritas masyarakat dapat diberdayakan dalam pembangunan baik itu pembangunan sosial budaya maupun pembangunan ekonomi. Pemberdayaan masyarakat dalam pembangunan ekonomi di desa diwujudkan dengan pembentukan Badan Usaha Milik Desa. BUMDes merupakan lembaga yang bertujuan untuk memberdayakan sektor ekonomi masyarakat di desa menuju kesejahteraan yang menjadi cita-cita pembangunan. Pembentukan BUMDes akan memberikan manfaat ekonomi terhadap masyarakat desa baik secaraindividu bagi yang terlibat di unit-unit usaha BUMDes juga dapat memberikan tambahan keuangan bagi kas desa sebagai PAD

Dalam Peraturan Menteri Desa, Pembangunan Daerah Tertinggal, dan Transmigrasi Republik Indonesia Nomor 4 Tahun 2015 Tentang Pendirian, Pengurusan dan Pengelolaan, dan Pembubaran Badan Usaha Milik Desa disebutkan bahwa Badan Usaha Milik Desa adalah badan usaha yang seluruh atau sebagian besar modalnya dimiliki oleh Desa melalui penyertaan secara langsung yang berasal dari kekayaan Desa yang dipisahkan guna mengelola aset, jasa pelayanan, dan usaha lainnya untuk sebesar-besarnya kesejahteraan masyarakat Desa. Tujuan pendirian BUMDes adalah :

a. meningkatkan perekonomian Desa;

b. mengoptimalkan aset Desa agar bermanfaat untuk kesejahteraan Desa;

c. meningkatkan usaha masyarakat dalam pengelolaan potensi ekonomi Desa;

d. mengembangkan rencana kerja sama usaha antar desa dan/atau dengan pihak ketiga;

e. menciptakan peluang dan jaringan pasar yang mendukung kebutuhan layanan umum warga;

f. membuka lapangan kerja;

g. meningkatkan kesejahteraan masyarakat melalui perbaikan pelayanan umum, pertumbuhan dan pemerataan ekonomi Desa; dan

h. meningkatkan pendapatan masyarakat Desa dan Pendapatan Asli Desa.

Keberadaan BUMDes sebagai lembaga penyangga ekonomi pedesaan harus mampu melibatkan mayoritas masyarakat desa dalam unit-unit usaha yang dimiliki. Sebagai lembaga pemberdayaan ekonomi masyarakat desa, keberadaan BUMDes merupakan wadah bagi masyarakat desa menuju kearah kesejahteraan. Pemerintah terus berupaya memberikan pemahaman kepada pemerintah desa akan pentingnya keberadaan lembaga ekonomi ini dalam pemberdayaan masyarakat desa. Dalam laman Kemendesa.go.id disebutkan bahwa Kementerian Desa, Pembangunan Daerah Tertinggal, dan Transmigrasi (Kemendes PDTT) mencatat hingga Desember 2018 sebanyak 61 persen desa telah memiliki Badan Usaha Milik Desa atau telah terbentuk sebanyak 45.549 unit BUMDes di Indonesia. Jumlah ini meningkat tajam dari tahun 2014 yang hanya memiliki 1.022 BUMDes. Hal ini menunjukkan bahwa pemahaman tentang pentingnya BUMDes sebagai lembaga pemberdayaan ekonomi masyarakat desa telah dipahami mayoritas desa yang ada di Indonesia sehingga sudah mampu mewujudkan badan usaha ini sebagai prioritas pembangunan khususnya pembangunan dalam bidang ekonomi.

Badan usaha milik desa dibentuk bertujuan untuk meningkatkan kesejahteraan masyarakat desa dan pengembangan desa menjadi desa yang mandiri. Meskipun saat ini sebagian besar desa sudah memiliki BUMDes, namun masih banyak badan usaha yang dimiliki tidak dikelola dengan baik. Masih banyak badan usaha desa dibentuk untuk memenuhi tuntutan pemerintah saja, namun pengelolaannya belum dilakukan secara maksimal. Dalam mengelola potensi desa yang akan diusahakan untuk menunjang proses pemban- 
gunan ekonomi di desa, badan usaha milik desa menghadapi berbagai permasalahan seperti yang dikemukakan oleh Kusuma dan Purnamasari (2016) diantaranya yakni:

a. Komunikasi;

b. Pemberdayaan masyarakat lokal;

c. Kapasitas manajerial;

d. Infrastruktur BUMDes;

e. Transparansi dan akuntabilitas laporan pertanggung jawaban.

Permasalahan yang dihadapi ini harus mampu diatasi oleh pemerintah desa agar lembaga ekonomi yang dibentuk ini dapat berjalan sesuai peruntukannya. Penguatan kapasitas kelembagaan BUMDes harus terus dilakukan agar sumber daya yang ada di desa mampu dioptimalkan peran sertanya dalam pembangunan.

\section{Pembangunan ekonomi desa melalui pendekatan partisipatif}

Pelaksanaan Undang-Undang Nomor 6 Tahun 2014 tentang Desa yang mengamanatkan alokasi dana dari Anggaran Pendapatan dan Belanja Negara serta Anggaran Pendapatan dan Belanja Daerah yang cukup untuk pembangunan di desa diharapkan mampu menjadikan desa sebagai subyek pembangunan. Peningkatan pembangunan infrastruktur di desa akan mampu meningkatkan kesejahteraan masyarakat terutama semakin cepatnya hasil-hasil pertanian dan produksi dari desa terserap di pasaran. Membangun desa berarti membangun Indonesia secara merata dan berkeadilan karena di desa mayoritas masyarakat negeri ini tinggal dan juga sebagian masih belum sejahtera. Desa yang maju akan menjadikan Indonesia sebagai negara yang maju dan sejahtera seperti yang diharapkan setiap pemerintahan. Menjadikan desa sebagai fokus pembangunan merupakan kebijakan yang sangat tepat demi terwujudnya masyarakat yang makmur dan berkeadilan.
Wahyuningsih (2019), menyebutkan bahwa salah satu bentuk fasilitas yang diberikan pemerintah pusat melalui mekanisme kebijakan fiskal adalah program dana desa. Kebijakan fiskal memiliki dampak multiplier terhadap perekonomian sehingga kebijakan pemerintah pusat melalui mekanisme dana desa ini diharapkan pada akhirnya dapat menanggulangi kemiskinan di Indonesia. Adanya alokasi dana desa ini akan menjadikan desa dapat berperan dan berkontribusi dalam pembangunan sehingga desa dapat menjadi ujung tombak bagi pelayanan publik dan peningkatan serta pemerataan kesejahteraan warga negara.

Undang-Undang Nomor 6 tahun 2014 tentang Desa merupakan aturan mengenai penyelenggaraan pemerintahan desa dimana desa pada saat ini telah mengalami perkembangan dalam berbagai bentuk sehingga perlu dilindungi dan diberdayakan agar menjadi kuat, maju, mandiri, dan demokratis untuk menciptakan landasan yang kuat dalam melaksanakan pemerintahan dan pembangunan menuju masyarakat yang adil, makmur dan sejahtera.

Pengaturan Desa bertujuan:

a. Memberikan pengakuan dan penghormatan atas Desa yang sudah ada dengan keberagamannya sebelum dan sesudah terbentuknya Negara Kesatuan Republik Indonesia;

b. Memberikan kejelasan status dan kepastian hukum atas Desa dalam sistem ketatanegaraan Republik Indonesia demi mewujudkan keadilan bagi seluruh rakyat Indonesia;

c. Melestarikan dan memajukan adat, tradisi, dan budaya masyarakat Desa;

d. Mendorong prakarsa, gerakan, dan partisipasi masyarakat Desa untuk pengembangan potensi dan Aset Desa guna kesejahteraan bersama;

e. Membentuk Pemerintahan Desa yang profesional, efisien dan efektif, terbu- 
ka, serta bertanggung jawab;

f. Meningkatkan pelayanan publik bagi warga masyarakat Desa guna mempercepat perwujudan kesejahteraan umum;

g. Meningkatkan ketahanan sosial budaya masyarakat Desa guna mewujudkan masyarakat Desa yang mampu memelihara kesatuan sosial sebagai bagian dari ketahanan nasional;

h. Memajukan perekonomian masyarakat Desa serta mengatasi kesenjangan pembangunan nasional; dan

i. Memperkuat masyarakat Desa sebagai subjek pembangunan.

Partisipasi masyarakat merupakan kunci utama suksesnya pelaksanaaan pembangunan yang dilaksanakan di desa. Partisipasi masyarakat akan menempatkan masyarakat desa sebagai motor penggerak atau sebagai subyek pembangunan bukan hanya sebagai obyek atau penerima manfaat saja. Dengan Partisispasi ini membuat masyarakat desa akan merasa memiliki serta ikut bertanggungjawab terhadap setiap proses dan hasil-hasil pembangunan. Partisipasi masyarakat akan mengarah kepada pemberdayaan masyarakat karena melalui partisipasi dalam seluruh proses, masyarakat akan semakin berdaya dan mampu mengendalikan proses tersebut kearah pencapaian kesejahteraan.

Mendorong partisipasi masyarakat dalam membangun Indonesia dari desa akan terwujud apabila pemerintah memiliki keinginan yang baik untuk melaksanakannya. Pemerintah wajib mendorong dan memberikan kesempatan kepada masyarakat untuk terlibat dalam pola partisipatif ini. Pola pembangunan desa yang partisipatif merupakan pemecahan masalah dalam mengatasi ketidak merataan pembangunan yang dialami bangsa dan negara saat ini. Mendorong partisipasi masyarakat desa secara maksimal dalam pembangunan akan menjadikan pembangunan yang dilaksanakan ini mampu mewujudkan tujuan nasional sesuai apa yang dicita-citakan bersama yakni masyarakat Indonesia yang adil danse- jahtera.

\section{Penguatan peran BUMDes menuju terwujudnya Desa Mandiri}

Desa sebagai daerah otonom memiliki hak untuk mengelola potensi desanya yang ditujukan kepada kemakmuran masyarakat desa setempat. Setiap desa memiliki potensi yang berbeda-beda, sehingga memerlukan kejelian dan pengetahuan yang cukup bagi warga desa dalam mengelola potensi tersebut. Pembangunan ekonomi yang dilaksanakan di desa memerlukan strategi dan melibatkan masyarakat desa masing-masing. Lembaga yang dibentuk oleh pemerintah desa untuk memperkuat perekonomian desa serta pemberdayaan masyarakat adalah Badan Usaha Milik Desa.

Badan Usaha Milik Desa merupakan pengejawantahan dari amanat Undang Undang Nomor 6 Tahun 2014 yang menyatakan bahwa BUMDes dibentuk atas dasar semangat kekeluargaan dan kegotongroyongan untuk mendayagunakan segala potensi ekonomi, kelembagaan perekonomian, serta potensi sumber daya alam dan sumber daya manusia dalam rangka meningkatkan kesejahteraan masyarakat desa. Penguatan peran BUMDes dalam mengembangkan usaha dan perekonomian masyarakat desa memerlukan penanganan yang komprehensif, sehingga tumbuhnya ekonomi nasional ditopang oleh perekonomian desa yang kokoh dan terarah. BUMDes sebagai lembaga ekonomi desa yang legal dan memiliki peran penting dalam meningkatkan usaha perekonomian masyarakat desa, perlu di dukung pemerintah sebagai basis pengembangan industri kecil dan menegah (Harmiati dan Zulhakim, 2017).

Ramadana et.al (2013) mengungkapkan bahwa posisi badan usaha milik desa dalam menghadapi realitas arus desak intervensi modal domestik dan asing yang kini menjadikan desa sebagai sasaran pengembangan usaha sangat keras sekali, disamping itu badan usaha milik desa ini hanya bermodal tak seberapa jika dibandingkan dengan 
swasta bermodal besar maka posisi badan usaha milik desa ini tak dapat dibandingkan. Dengan sumberdaya alam yang dimiliki oleh desa, hal ini sangat rawan sekali terjadi intervensi modal dan pasar di pedesaan. Kehadiran badan usaha milik desa ini sendiri akan menjadi penangkal bagi kekuatan korporasi asing dan nasional. Diharapkan badan usaha milik desa mampu menggerakkan dinamika ekonomi desa, dan sebagai perusahaan desa.

Badan usaha milik desa yang dikelola dengan baik, akan mampu memberikan lapangan pekerjaan kepada masyarakat karena tujuan utama pendirian BUMDes adalah pemberdayaan menuju peningkatan kesejahteraan masyarakat desa. Dampak lainnya apabila badan usaha ini dikelola secara profesional adalah sumbangan terhadap pendapatan desa yang tinggi. Pendapatan dari badan usaha ini dapat dialokasikan oleh pemerintah desa dalam pelaksanaan pembangunan di desa baik fisik maupun non fisik. BUMDes yang maju dan kuat akan mampu memberikan manfaat maksimal terhadap masyarakat dan pembangunan di desa dalam mewujudkan desa yang mandiri.

Menurut Nursetiawan (2018), Desa mandiri merupakan desa yang mampu memenuhi kebutuhannya dan apabila terdapat bantuan dari Pemerintah, bantuan tersebut hanya bersifat stimulus. Pembangunan desa mandiri meliputi kegiatan-kegiatan rencana pembangunan yang bersifat partisipatif, transparan, akuntabel dan mendetail. Adapun strategi yang dapat dilakukan untuk mencapai desa mandiri tersebut dengan melakukan implementasi inovasi di setiap sendi lembaga usaha Badan Usaha Milik Desa. Selain itu dilakukan optimalisasi di setiap aset desa dan potensi desa untuk peningkatan kesejahteraan masyarakat.

Desa yang maju dan mandiri merupakan desa yang mampu mengelola aset dan potensi yang dimiliki serta mampu memanfaatkan peluang yang ada dalam pengelolaan pembangunan untuk kesejahteraan warga desa. Penguatan kelembagaan BUMDes ha- rus dijadikan prioritas oleh pemerintah desa yang didukung oleh seluruh lapisan masyarakat. Usaha desa yang dikelola secara baik akan memberikan manfaat yang sangat besar bagi kehidupan masyarakat desa. Masyarakat akan menerima manfaat secara individu utamanya yang terlibat secara langsung dalam usaha desa ini. Selain itu BUMDes yang memiliki sisa hasil usaha/keuntungan yang besar akan memberikan Pendapatan Asli Desa (PAD) kepada pemerintah desa yang dapat digunakan dalam pembangunan desa menuju peningkatan kesejahteraan masyarakat desa.

\section{PENUTUP \\ Simpulan}

BUMDes dibentuk sebagai lembaga pemeberdayaan ekonomi masyarakat desa yang bertujuan untuk meningkatkan kesejahteraan masyarakat desa dan pengembangan desa menjadi desa yang mandiri. Saat ini sebagian besar desa sudah memiliki BUMDes, namun masih banyak badan usaha desa tidak dikelola dengan baik, sehingga belum mampu menjadi badan usaha yang dapat menyangga perekonomian desa dan juga memberikan tambahan pendanaan dalam Anggaran Pendapatan dan Belanja Desa.

Pola pembangunan yang partisipatif merupakan pemecahan masalah dalam mengatasi ketidak merataan pembangunan yang dialami bangsa dan negara saat ini. Partisipasi seluruh masyarakat dalam pembangunan khususnya pembangunan ekonomi telah mampu memperkuat sendi-sendi perekonomian desa. Pola partisipatif ini menjadikan masyarakat lebih berdaya khususnya dalam bidang ekonomi sehingga kemiskinan yang banyak jumlahnya di desa dapat ditekan.

Lembaga usaha desa yang dikelola secara baik akan memberikan manfaat yang sangat besar bagi kehidupan masyarakat desa. Masyarakat akan menerima manfaat secara individu utamanya yang terlibat secara langsung dalam usaha desa ini. Selain itu BUMDes yang memiliki sisa hasil usaha/keuntungan 
yang besar akan memberikan Pendapatan Asli Desa kepada keuangan pemerintah desa yang digunakan dalam pembangunan desa yang bertujuan untuk meningkatkan kehidupan ekonomi masyarakat.

\section{Rekomendasi}

Masih banyaknya pengelolaan BUMDes yang kurang baik mengakibatkan peran BUMDes belum maksimal dalam meningkatkan perekonomian masyarakat desa. Tata kelola dan kurangnya pengetahuan kewirausahaan pengurus BUMDes merupakan masalah yang paling banyak dialami oleh BUMDes sehingga keberadaan lembaga perekonomian desa ini belum mampu meningkatkan PAD dan meningkatkan kesejahteraan masyarakat. Pemerintah baik pusat maupun daerah diharapkan terus melakukan pembinaan kepada pengelola BUMDes, sehingga lembaga ini dapat berkembang dengan baik. Pemerintah desa diharapkan terus memberikan dukungan kepada keberadaan BUMDes baik berupa dukungan penguatan kelembagaan maupun dukungan penguatan modal.

\section{DAFTAR PUSTAKA}

Fkun, Igedius. 2019. Eksistensi Badan Usaha Milik Desa Dalam Meningkatkan Perekonomian Masyarakat Di Desa Subun Bestobe Kecamatan Insana Barat. Jurnal Poros Politik Vol. 1 No. 1 (2019)

Hakim, Lukman. 2011. Pengantar Administrasi Pembangunan. Jogjakarta. Ar-Ruzz Media.

Harmiati dan Zulhakim, Abdul Azis. 2017. Eksistensi Badan Usaha Milik Desa (Bumdes) Dalam Mengembangkan Usaha Dan Ekonomi Masyarakat Desa Yang Berdaya Saing Di Era Masyarakat Ekonomi Asean. Jurnal Unihaz Bengkulu, Cluster Ekonomi. Setnas ASEAN

Kusuma, Gabriella Hanny dan Purnamasari, Nurul, 2016. BUMDES: Kewirausahaan Sosial yang Berkelanjutan (Analisis Potensi dan Permasalahan yang dihadapi Badan Usaha Milik Desa di Desa Ponjong, Desa Bleberan, dan Desa Sumbermulyo) .Yogyakarta. Penabulu Foundation

Nursetiawan, Irfan, 2018. Strategi Pengembangan Desa Mandiri Melalui Inovasi Bumdes. Moderat: Jurnal Ilmiah Ilmu Pemerintahan Vol.4. No. 2.

Peraturan Menteri Desa, Pembangunan Daerah Tertinggal, dan Transmigrasi Republik Indonesia Nomor 4 Tahun 2015 Tentang Pendirian, Pengurusan dan Pengelolaan, dan Pembubaran Badan Usaha Milik Desa

Ramadana, Coristya Berlian., Ribawanto, Heru., dan Suwondo. 2013. Keberadaan Badan Usaha Milik Desa (Bumdes) Sebagai Penguatan Ekonomi Desa (Studi di Desa Landungsari, Kecamatan Dau, Kabupaten Malang). Jurnal Administrasi Publik (JAP), Vol. 1, No. 6, Hal.1068-1076

Santoso, Pandji. 2017. Administrasi Publik: Teori dan Aplikasi Good Governance. Bandung. Refika Aditama.

Sugiyono. 2014. Memahami Penelitian Kualitatif. Bandung. PenerbitAlfabeta.

Suprayitno, Bambang. 2017. Ekonomi Publik, Konsep dan Implemetasi Kebijakan, Yogyakarta. UPP STIM YKPN

Undang-Undang Republik Indonesia Nomor 6 tahun 2014 tentang Desa

Undang-Undang Republik Indonesia Nomor 23 tahun 2014 tentang Pemerintahan Daerah.

Wahyuningsih, Tri. 2019. Ekonomi Publik. Depok. Rajawali Pers.

h t t p s : / / b p s . g o. id / p res s re lease/2020/01/15/1743/persentase-penduduk-miskin-september-2019-turunmenjadi-9-22-persen.html (Accessed 18 Juli 2020)

https://kemendesa.go.id/ berita/view/ detil/2862/tercatat-sebanyak-61-persen-desa-telah-memiliki-bumdes (Accessed 27 Juli 2020) 